\title{
Recent Payment Account Prices Information Asymmetry Reduction Regulation Impact in the EU
}

\author{
Ivan SOUKAL \\ University of Hradec Kralove, Hradec Kralove, Czech Republic \\ ivan.soukal@uhk.cz
}

\begin{abstract}
Approximately ten years after the EU studies and expert groups had collected evidence on transparency issues related to the payment account prices and offer real-world measures came into force. Directive 2014/92/EU (also known as Payment Account Directive) stated that in cooperation with the European Banking Authority and national regulators should be introduced in member states ex-ante indicator Fee Information Document, ex-post indicator Statement of Fees and standardised terms list. The goal of the paper is to perform an early assessment of Fee Information Document adoption linked to standardised terms list in the Czech Republic by payment account providers. The Fee Information Documents of ten Czech and four United Kingdom banks are compared between. The discrepancies in the level of detail, the problem of fragmentation related to payments and overdraft facility inclusion were found. These issues may prevent reaching the goal of the regulation in terms of providing consumers with a document that is concise, standardised and easy to compare different payment account offers.
\end{abstract}

Keywords: Payment account, Regulation, Directive 2014/92/EU, European Banking Authority, Fee Information Document.

\section{Introduction}

The information asymmetry is natural imperfection regarding any real-world market and so there is no reason why the market of payment account (PA, PAs in plural) for individuals should be an exception. The paper is focused on accounts through which consumers are able to carry out funds placing, cash withdrawals, execute and receive payments to and from accounts of another provider. Therefore, any other account not providing all such services, e.g. electronic wallets, pre-paid services accounts, credit card account, is beyond the scope.

EU studies and expert groups $[3,10,19]$ collected evidence focused on issues of transparency in form of incompleteness, complexity and the links between financial products. Two main aspects were identified; how clear and comparable is information provided to consumers and; how aware consumers are of the fees they are charged. Other local empirical studies were in accordance to the conclusions such as [17], TNS at the request of D-G for Health and Consumers, Office of Fair Trading, UK Independent Commission on Banking, UFC-Que Choisir etc. Generally speaking, fees 
and costs related to banking products tend to be one of the main reasons for consumer complaints. It is particularly in terms of a lack of transparency that impedes consumers from making well-informed choices; the comparability of fees; and pricing. [6] There was observed an increase of PA related complaints in 2017 with EU average of $49 \%$ of all complaints received by competent authorities.[7]

The Directive 2014/92/EU [11] (also known as Payment Account Directive) was adopted as an action to remove barriers to competition within the internal market and to increase a consumer protection in retail banking. Understanding the fees is a prerequisite for being able to compare PA offers and key for consumers to make informed decisions. Therefore, two indices and one enabler/enhancer tools were introduced in the [11]; ex-ante indicator Fee Information Document (FID, FIDs in plural), ex-post Statement of Fees (SOF) and standardised terms glossary. After the transposition of [11] into national legal environment and with assistance of European Banking Authority (EBA) PA providers in member states started to publish their FIDs at the beginning of the winter 2018 .

The goal of the paper is to perform an early assessment of this effort to provide consumers with information that is concise, standardised and easy to compare between different PA offers. To reach this goal the FIDs of the Czech PA providers will be compared between and to United Kingdom's (UK) FIDs. An attention paid to the PA market is justified since the importance of the PA product is great. EU sees barriers on the PA market as barriers to the deployment of a fully integrated market [11]. Both EU legal bodies as well as academicians stress also a social function of the PA. EU acknowledges that socially inclusive economy increasingly depends on the universal provision of payment services. depicts The study [4] points out a positive relationship between gross domestic product and an access to basic banking services (current account and payment services) and credit and $[1,13]$ connects the financial inclusion with an overall bank system stability.

\section{$2 \quad$ Research and Methods}

\subsection{Payment Account and Information Asymmetry Reduction Effort}

In general, providing clear and comparable information on service offers is a prerequisite for the free operation of market forces. Although it is difficult to measure the level of market imperfections, e.g. in form of dead weight costs, caused by nontransparent, incomparable fee information, it is likely that all consumers are adversely impacted by these issues at some point. A certain approach was adopted in the study [17] where an optimal PA choice was assessed accordingly the range of demanded services and the price paid for a PA that offers such services. The analysis was consisted of consumers with activated e-banking, using basic account features, see. [11], no service demanded at a branch. The $95 \%$ confidence interval for mean of optimal choice was $(20.45 ; 21.28)$ in $\%$. Such low values were explained by multiple factors but the main one was related to information asymmetry in for of lack of price transparency combined with a low expected rate of return. 
EU-wide studies were performed, and expert groups formed to further describe and analyse this issue. Expert group point of view was that: "Consumers tend to use imperfect proxies for identifying alternative products (brands, reputation, proximity) instead of prices and contract terms and conditions"[10] However, the main result of the report related to the problem of transparency. PAs prices are difficult to compare because the information is available in a way that implies high search costs. Those costs come from the problem of tariffs incompleteness, complexity and the links between financial products. The latter issue of links between financial products does not relate to natural links but tying, bundling, conditional sales and cross-selling practices. Such practices even further increase overall complexity of total price calculation and so the problem of transparency as well. The most common in the Czech Republic would be conditional practices which relates to offers that entail better contract conditions or price reduction if certain condition is met. This one is also known for so-called loyalty prices. These problems practices studied in [3] and the magnitude and spread of the practices was substantial: "More than $50 \%$ of providers estimate the share of consumers involved in some form of bundling higher than $80 \%$. Mixed bundling with rebates relates to $35 \%$ and without rebate $60 \%$ of consumers". The third study to be mentioned was to deal with the comparability issue. The main findings were that comparability varies across the EU and at the same time there is a negative correlation between the price (costs) and the level of transparency [19]. Also, the researchers had problem in price calculation even though their test profile was not very complex. They had to contact $40 \%$ of the providers to confirm data collectors' interpretations of prices or additional tariff clarifications. $33 \%$ the price information in their tariff lists was found to be incomplete. Thus, EU consumers bear a negative outcome of this information asymmetry related to both the real nature of the service and mainly to the price transparency issues. In general, PA fees are the most common reason of consumer complaints in the EU $[6,7]$.

An effort to tackle the issues related to information asymmetry lead to the Directive 2014/92/EU which was later in the Czech Republic transpositioned by the law no. 452/2016 Coll. Among other tools, such as comparison websites, the directive introduced:

- List of standardised terms: standardised terminology was introduced in order to overcome an issue, that payment service providers use different terminology for the same services and provide information in different formats. The terminology should have covered the most representative services linked to payment account. This list should have been an enabler or at least experience enhancer for the next two obligatory documents accompanying the offer and use of PA.

- Fee information document (FID): FID states the fees for all services contained in the list of the most representative services linked to a payment account at national level. The FID should use the standardised terms and definitions established at EU level. The FID should not contain any other fees. Where a payment service provider does not offer a service appearing in the list of the most representative services linked to a payment account, it should indicate this by, for example, marking the service as 'not offered' or 'not applicable'. PA provider should provide the consumer, in good 
time before entering into a contract for a payment account with a consumer, with a FID on paper or another durable medium. Therefore, the FID serves as an ex-ante fee indicator.

- Statement of fees (SoF): ex-post fee information should be provided in a dedicated document. It should provide an overview of interest earned and all the fees incurred in relation to the use of the payment account to enable a consumer to understand what fee expenditures relate to and to assess the need to either modify consumption patterns or move to another provider. SoF should be presenting the most representative services in the same order as the FID.

Member states mostly through their bank market supervisors submitted lists of the most representative services related to fees charged at PAs to EBA. After the consultation period EBA had published the list of standardised terminology for PA those services that are common to at least a majority of member states.[8] EBA drafts then came into force by the Regulation EU 2018/32 [9] and in member states it usually came into force in form of a regulator's decree such as the case of The Czech Republic [5]. The decree came into force on October $31^{\text {st }}, 2018$ providing final list of most representative services linked to payment account and fees in the Czech Republic.

\subsection{Comparison}

Since the paper is focused on the [11] impact on the retail PA offer, the attention was paid at first on the difference between the EU and Czech list of standard terms including services and their aspects. Compared account are chosen to be mainstream PA without features for affluent consumers or consumers that comply any other special conditions related to age, income etc. The next part compared the length and structure of FIDs that have been already available in the Czech Republic. The aim is at the most complex parts of the FIDs since the FID should above anything else easy the comparability and offer. Then the results were compared to the FIDs of global systemically important banks with headquarters in the UK. Global systemically important banks were chosen since activity of certain banks is essential and irreplaceable for the whole economic activity [18]. This group represents the most important bank institutions in the world accordingly the criteria of size, cross-jurisdictional activity, system interconnectedness and other variables since 2009. This state lasts till now in 2018 [2] and this group continues to be more systematically important than other banks, implying that perception of "too-big-to-fail" remains or as [18] notes "too-interconnected-to-fail". Their key role in the financial system also puts them in a position where their problems rapidly spread over to non-systemic financial institutions. [14] The importance of such banks is obvious and because they take part in the retail banking they were chosen as a sample the Czech PA offer to be compared to. The data were collected during the second week of December 2018. The fig. 1 shows the result of EBA effort to prepare FID accordingly the [11], EBA's own testing with consumers in a qualitative and quantitative consumer-testing exercise, and consultation on them between September and December 2016. The FID is divided into groups of services: 
- General Account Service,

- Payments (excluding cards),

- Cards and cash,

- Overdrafts and related services,

- Other services.

\section{Fee Information Document}

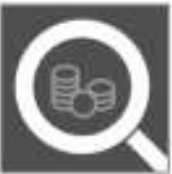

Name of the account provider:

Account name:

Date:

- This document informs you about the fees for using the main services linked to the payment account. it will help you to compare these fees with those of other accounts.

- Fees may aiso apply for using services linked to the account which are not listed here. Full information is available in ispecify names of the relevant pre-contractual and contractual documents].

- A glossary of the terms used in this document is avaliable free of charge.

\begin{tabular}{|l|l|}
\hline Service & Fee \\
\hline General account services \\
\hline [main service] [brand name] & [0]
\end{tabular}

Fig. 1. Sample of obligatory FID template developed by EBA, annex of [8].

\section{Results}

\subsection{Standardised terminology}

Standardised terminology is the base of the FID. The table below compares all member states common standardised terminology and Czech final list of the most representative services linked to a PA and subject to a fee. 
Table 1. Table captions should be placed above the tables $[5,9]$.

\begin{tabular}{lll}
\hline $\begin{array}{l}\text { Standardised terms for } \\
\text { services }\end{array}$ & $\begin{array}{l}\text { Commission Delegated } \\
\text { Regulation (EU) 2018/32 }\end{array}$ & $\begin{array}{l}\text { Czech National Bank Decree } \\
\text { No. 74/ 2018 Coll. }\end{array}$ \\
\hline Maintaining the account & included & included \\
Providing a debit card & included & included \\
Providing a credit card & included & not included \\
Overdraft & included & inclually included in greater detail \\
Credit transfer & included & included \\
Standing order & included & included \\
Direct debit & included & included \\
Cash withdrawal & included & included \\
Sending an informative SMS & not included & included \\
Monthly statement & not included &
\end{tabular}

The table shows some national differences to the list of standardised terms by EBA. This is the result and in accordance to [11] article 3(1). Yet, for the first sight, it may be surprising that the credit card provision is not included in the Czech final list of the most representative services linked to a payment account and subject to a fee. Nevertheless, banks in the Czech Republic provide credit cards in a different way which not linked with the payment account. A credit card provision and usage in form of a loan contract and it does not even require the client to have a payment account at the bank he or she applies for a credit card. The overdraft facility is included only in form of a note that a debit card allows to dispose of money including previously arranged authorized overdraft. Nevertheless, the overdraft itself in terms of interest rate of fees for a PA balance below zero etc. is not included since provision of a debit card is not fixed on authorized overdraft. Credit transfer was included in a slightly greater detail separating incoming and outgoing payment. Two items were added to the Czech final list in comparison to the list from the Regulation [9]. These two items came from the national provisional list submitted to EBA because they act in almost all PAs' price lists in the Czech Republic as services not provided for free.

\subsection{Fee Information Document}

FID comparison was at first focused on the global systemically important banks and the PAs they offer at a country of their origin i.e. headquarters. The adoption of FID was faster in the UK, Scandinavia or the Czech Republic compared to France and Germany also due to a national regulator. Therefore, the table below contains mostly UK banks.

Table 2. FIDs of global systemically important banks overview in the country of origin.

\begin{tabular}{|c|c|c|c|c|}
\hline Bank & FID & Account & Pages & Most complex group of services \\
\hline Barclays & yes & $\begin{array}{l}\text { Barclays } \\
\text { Bank } \\
\text { Account }\end{array}$ & 3 & $\begin{array}{l}\text { Payments (excluding cards): various conditions } \\
\text { applied to domestic, cross-border, and international } \\
\text { payments (especially overseas). }\end{array}$ \\
\hline
\end{tabular}




\begin{tabular}{|c|c|c|c|c|}
\hline HSBC & yes & $\begin{array}{l}\text { HSBC Bank } \\
\text { Account }\end{array}$ & 1.5 & $\begin{array}{l}\text { Payments (excluding cards): various conditions } \\
\text { applied to mostly domestic (network type, } \\
\text { communication channel) and outside UK. }\end{array}$ \\
\hline $\begin{array}{l}\text { Royal } \\
\text { Bank of } \\
\text { Scotland }\end{array}$ & yes & $\begin{array}{l}\text { Bank account } \\
\text { Select }\end{array}$ & 2 & $\begin{array}{l}\text { Overdrafts and related services: arranged an } \\
\text { unarranged overdraft }\end{array}$ \\
\hline $\begin{array}{l}\text { Standard } \\
\text { Chartered }\end{array}$ & yes* & --- & --- & --- \\
\hline $\begin{array}{l}\text { Royal } \\
\text { Bank of } \\
\text { Scotland }\end{array}$ & yes & $\begin{array}{l}\text { Bank account } \\
\text { Select }\end{array}$ & 2 & $\begin{array}{c}\text { Overdrafts and related services: arranged an } \\
\text { unarranged overdraft }\end{array}$ \\
\hline
\end{tabular}

*only private banking is offered in the UK (year fee equivalent to 3.000 USD) which is a very specific market segment beyond the scope of the paper.

The table shows that implicit goal (comes from the consultation prior to the [8]) of a single sheet of two pages where the consumer will be briefly informed was mostly achieved. This goal was mentioned also in the discussion during the EBA preparation of [8].

Only two bank The situation in the Czech Republic is ahead of most of other European countries when there are only a few exceptions among bank with a republicwide retail network.

Table 3. FIDs of banks with a republic-wide retail network in the Czech Republic.

\begin{tabular}{|c|c|c|c|c|}
\hline Bank & FID & Account & Pages & Most complex \\
\hline Air Bank & yes & Malý tarif & 1.5 & General account services: package of services \\
\hline $\begin{array}{l}\text { BNP Paribas } \\
\text { Personal Finance } \\
\text { (Hello bank) }\end{array}$ & yes & $\begin{array}{l}\text { Běžný } \\
\text { účet }\end{array}$ & 1.5 & $\begin{array}{l}\text { General account services: detailed options } \\
\text { concerning a debit card provision }\end{array}$ \\
\hline Česká spořitelna & yes & $\begin{array}{l}\text { Účet s } \\
\text { MZF* }\end{array}$ & 3.5 & General account services: packages of services \\
\hline $\begin{array}{l}\text { Československá } \\
\text { obchodní banka }\end{array}$ & yes & $\begin{array}{l}\text { Plus } \\
\text { Konto }\end{array}$ & 4 & $\begin{array}{l}\text { Payments (excluding cards): various conditions } \\
\text { applied to domestic payments (communication } \\
\text { channel, establishing, execution, change of } \\
\text { payment, priority) and cross-border payments } \\
\text { (communication channel, amounts) and more }\end{array}$ \\
\hline $\begin{array}{l}\text { Československá } \\
\text { obchodní banka } \\
\text { (Poštovní banka) }\end{array}$ & yes & $\begin{array}{l}\text { Poštovní } \\
\text { účet }\end{array}$ & 3.5 & $\begin{array}{l}\text { Payments (excluding cards): various conditions } \\
\text { applied to domestic payments (communication } \\
\text { channel, establishing, execution, change of } \\
\text { payment, priority) and cross-border payments } \\
\text { (communication channel, amounts) and more }\end{array}$ \\
\hline Equa bank & yes & $\begin{array}{l}\text { Běžný } \\
\text { účet }\end{array}$ & 1.5 & $\begin{array}{l}\text { Payments (excluding cards): different types of } \\
\text { incoming and outgoing payments }\end{array}$ \\
\hline Fio banka & no & --- & --- & --- \\
\hline Komerční banka & yes & MůjÚucet & 5 & $\begin{array}{l}\text { Payments (excluding cards): two pages of various } \\
\text { conditions applied to payments (type, territory, } \\
\text { communication channel, establishing, execution, } \\
\text { change of payment, priority, inter or intra-bank, } \\
\text { amounts and more) }\end{array}$ \\
\hline
\end{tabular}




\begin{tabular}{|c|c|c|c|c|}
\hline mBank & yes & mKonto & 4.5 & $\begin{array}{l}\text { Cards and cash: four different types of cards each } \\
\text { with some differences in cash utilization, } \\
\text { maintenance fee, second card option etc. }\end{array}$ \\
\hline Moneta & no & --- & --- & --- \\
\hline Raiffeisenbank & no & --- & --- & -- \\
\hline Sberbank CZ & yes & $\begin{array}{l}\text { FÉR } \\
\text { konto } \\
\text { MINI }\end{array}$ & 2 & $\begin{array}{l}\text { Payments (excluding cards): various conditions } \\
\text { applied to mostly cross-border payments }\end{array}$ \\
\hline $\begin{array}{l}\text { UniCredit Bank } \\
\text { Czech Republic } \\
\text { and Slovakia }\end{array}$ & yes & U konto & 5 & $\begin{array}{l}\text { Payments (excluding cards): two pages of various } \\
\text { conditions applied to payments (type, territory, } \\
\text { communication channel, establishing, execution, } \\
\text { change of payment, priority, inter or intra-bank, } \\
\text { amounts and more) }\end{array}$ \\
\hline
\end{tabular}

*PA „Účet s Moje zdravé finance“ was chosen since the FID is not available for the most common account "Osobní konto".

The table shows that the main retail banks in the Czech Republic (Česká spořitelna, Komerční banka, Československá obchodní banka and UniCredit) published the longest and overall the most complex FIDs. Nevertheless, mBank that was one of the first low-cost e-banking oriented AP provider in the Czech Republic published the FID of the same length. Yet, the factor of complexity differs and so the complexity assessment is more complicated. Different detail was observed regarding e.g. the card service. Most of the banks included the information on the costs of providing a debit card or cards but mBank and Hello bank included a different ways of card delivery such as door-to-door courier service, different card types, the first and the second possible card to PA etc. Similarly, some banks included a very detailed options regarding the priority of the payments.

Another difference is related not the level of detail but to packages. Most of the banks included packages in the first part General account services but some banks included package options at the end of the FID in Other services or in a case of Česká sporitelna there are two special boxes Service package. These boxes are situated at the end of the FID even though one package of services is already present in the first category General account services. The mBank also included one package in the last part of the FID however this package was just a volume sale of informative SMS messages. This is in accordance to [5] and a case other than Česká spořitelna with package concerning the cash withdrawal and the second one concerning payments.

Yet, the most complex part was related to payments (excluding cards). It arises from a fragmentation of tariffs and price lists by various criteria:

- payer or payee,

- territory,

- communication channel,

- payment instrument,

- operation,

- priority,

- amount, 
- bank or bank group,

- cancellation.

Text-book examples of such fragmentation approach are Komerční banka, Československá obchodní banka and Poštovní banka. The last one also included a fee for SEPA payment in a way that e.g. SEPA payment established by electronic means costs 250 CZK but right below then there is " +250 CZK". This means that per SEPA item the fee is $250 \mathrm{CZK}$ but then at the end there is a fixed sort of manipulation fee of additional $250 \mathrm{CZK}$.

The FIDs did not contain information on an authorized overdraft in spite of being a part of the debit card provision term in the final list of the most representative services in the Czech Republic. The banks were supposed to either provide an information on overdraft on mark the service as 'not offered' or 'not applicable'. It is true that the final list of the most representative services in the Czech Republic only suggest overdraft inclusion in form of "in the case of an agreed overdraft facility". Nevertheless, most of the banks do offer an overdraft allowing to use credit money through the debit card.

\section{Discussion}

The Czech final list of the most representative services linked to a PA and subject to a fee differs accordingly the local difference to other member states. Missing" credit card provision could be explained by the more loan-service that PA-service approach and the next interpretation is that the provision itself is not a source of the fees. Even though the credit card would be linked to the PA then the interest and grace period would be included instead of a provision fee. These two features are the most determining concerning the total costs and the consumer's decision making. The way how the authorized overdraft is included in the Czech final list of the most representative services linked to a payment account and subject to a fee leaves great space for banks how and whether to include any overdraft information at all. However, generally speaking, the goal that the fee terminology should only be standardised for the most representative terms and definitions in order to avoid the risk of excessive information, was achieved in the Czech Republic. The problem lies elsewhere - the level of detail and the fragmentation.

It seems that different banks took a different approach i.e. choosing a bit different level od detail. There are banks such as mBank and Hello bank which included a very detailed options related to a debit card provision, card types and usage. On the other hand, Komerční banka offers different types of debit cards as well but only one type is included in the FID. Moreover, there are different fees related to debit card "Embosovaná karta" and "Plus karta". The difference in the level of detail may confuse a consumer and mBank's FID could be shorter by almost three pages making it shorter by approximately $60 \%$. The level of detail creates a similar problem to package incorporation. For example, Česká Spořitelna included one package of services into the first part of the FID and two more packages of services into the last one. On the other hand, most of the banks provide a package of services information ion the first part as it was meant to. Packages of certain pre-paid usage frequency of one particular service 
are mostly included at the part where the service is described (e.g. informative SMS package). To sum the problem up, the different level of detail may render the FID incomparable and confusing for a consumer.

The service fragmentation was present especially in the FIDs of the largest retail banks. The most complex FIDs contained 8 or 9 payment criteria prolonging the document into 4 or 5 pages. Such FID is mostly just a part of the price list which was an original source of complexity and transparency issues. An obligatory duty to provide a consumer with the FID on paper or another durable medium then leads to just printing a significant part of a price list which is already published. The idea to include in the standardised fee terminology only the most representative services in order to avoid the risk of excessive information was correct. The Czech National Bank was following it in [5]. Yet, due to a different level of detail and different pricing methods the goal to provide relevant information in a way that enhances comparison and transparency is not achieved.

It is unclear why no information on overdraft was provided in the surveyed FID of the Czech PA providers. Most of them offer authorized overdraft facility and yet there is no information on overdraft fees and neither an interest rate. This is in a sharp contrast to the UK. It is true that an overdraft is much more frequently used by much larger share of consumers than in the Czech Republic, yet it is a part of the EBA's list of the most representative services linked to a PA. Therefore, it would be confusing for a consumer at least from other EU member states not to find an overdraft information in the Czech FIDs.

The result interpretation of the comparison between global systemically important banks and the Czech retail banks is firstly that there is much larger variety in the Czech Republic. The variety does not refer to only range of services but mainly to variety of the fee structure. This finding is in accordance with studies $[3,12,16,19]$ identifying large variety of fees and charges that as a result decrease the transparency of the PA offer. Nevertheless, the result can be much different in a near future since now only a small sample of global systemically important banks' FIDs available at the moment (the second week of December 2018).

\section{Conclusion}

Approximately ten years after the EU studies and expert groups [3, 10, 19] had collected evidence on transparency issues related to the PA offer real-world measures came into force. EU commission by the directive [11] instructed EBA to issue guidelines [8] to assist the member states in preparation of three main instruments: list of most representative services linked to PA and fees, FID and SoF. The decree [5] came into force on October $31^{\text {st }}, 2018$ in the Czech Republic and so the retail banks started to publish the FIDs accordingly.

The content of each fee information document provided to consumers depends on the individual payment service provider's offer of services and on each member state's final list of the most representative services linked to a payment account. Yet, the adoption approach to FIDs shows discrepancies among the Czech PA providers as well 
as compared to the UK ones. The main identified issues are firstly related to a different level of detail mainly in debit card provision and services. Secondly, there is significant fragmentation in the main PA providers' FIDs. Banks such as Česká Spořitelna, Komerční banka, and Československá obchodní banka included a large variety of criteria according to which the payments are charged. Up to 8 criteria for payment fee distinguishing are applied in their FIDs at the same time. This increased the length of such FIDs up to 4.5 pages which is e.g. more than double the pages of FIDs in the UK. Thirdly, only Česká Spořitelna and UniCredit included at least some information about an overdraft facility in spite of the fact that an overdraft is part of the EBA's list of the most representative services linked to a PA. This situation was caused likely by only partial inclusion of an overdraft in the Czech final list of the most representative services linked to a PA instead of a separate item. These are the main issue to be tackled with in a future otherwise the regulation goal will not be fulfilled in terms of providing consumers with document that is concise, standardised and easy to compare different PA offers.

The next research should follow the changes in the pricing and FIDs of the banks during the next year to study whether it will cause some reaction. It is not for the first time when EU directive last time EU directive intervention changed the PA fees situation and caused step-by-step fee transfer to other PA services or other financial products [15]. Second aim of the next research should compare the FIDs among more countries as the PA providers will one-by-one publish their FIDs in the next year.

Acknowledgements. This paper was written with the financial support of Specific Research Project "Investments within the Industry 4.0 concept" 2018 at Faculty of Informatics and Management of the University of Hradec Králové to the Department of Economics. I would like to thank Martin Král for his down-to-earth comments.

\section{References}

1. Ahamed, M.M., Mallick, S.K.: Is financial inclusion good for bank stability? International evidence. Journal of Economic Behavior \& Organization. In Press, Corrected Proof (2017) DOI: 10.1016/j.jebo.2017.07.027.

2. Bańbuła, P., Iwanicz-Drozdowska, M.: The systemic importance of banks - name and shame seems to work. Finance Research Letters. 18(August 2016), 297-301 (2016). DOI: 10.1016/j.frl.2016.05.001.

3. Centre for European Policy Studies, Van Dijk Management Consultants: Tying and other potentially unfair commercial practices in the retail financial services sector, http://ec.europa.eu/finance/consultations/2010/tying/docs/report_en.pdf, last accessed $2018 / 11 / 26$

4. Corrado, G., Corrado, L.: Inclusive finance for inclusive growth and development. Current Opinion in Environmental Sustainability. 24(February 2017), 19-23 (2017). DOI: 10.1016/j.cosust.2017.01.013.

5. Czech National Bank: Decree No. 74/ 2018 Coll. of 25 April 2018 on services linked to payment account covered by the standardised terms, https://www.cnb.cz/miranda2/export/sites/www.cnb.cz/cs/legislativa/vyhlasky/vyhlaska_7 4_2018.pdf, last accessed 2018/11/26. 
6. European Banking Authority: EBA Consumers Trends Report 2016, https:/eba.europa.eu/documents/10180/1360107/Consumer+Trends+Report+2016.pdf, last accessed 2018/11/26.

7. European Banking Authority: EBA Consumers Trends Report 2017, https://eba.europa.eu/documents/10180/1720738/Consumer+Trends+Report+2017.pdf, last accessed 2018/11/26

8. European Banking Authority: Final Report on Draft Regulatory Technical Standards under Directive (2014/92/EU EBA/RTS/2017/04; EBA/ITS/2017/03; EBA/ITS/2017/04), https://eba.europa.eu/documents/10180/1837359/Final+draft+RTS+and+ITSs+under+PA D+\%28EBA-RTS-2017-04\%2C\%20EBA-ITS-2017-03\%2C\%20EBA-ITS-201704\%29.pdf, last accessed 2018/11/26.

9. Council of the European Union: Commission Delegated Regulation (EU) 2018/32 of 28 September 2017 supplementing Directive 2014/92/EU of the European Parliament and of the Council with regard to regulatory technical standards for the Union standardised terminology for most representative services linked to a payment account. Official Journal of the European Union. L 6/3.

10. European Commission: Expert group on customer mobility in relation to bank accounts, http://ec.europa.eu/internal_market/finservices-retail/docs/baeg/report_en.pdf, last accessed 2016/07/12.

11. Council of the European Union: Directive 2014/92/EU of the European Parliament and of the Council of 23 July 2014 on the comparability of fees related to payment accounts, payment account switching and access to payment accounts with basic features. Official Journal of the European Union. L 257/214.

12. Hedvicakova, M., Pozdilkova, A.: Multi-criteria analysis for the most efficient selection of bank account for young people. In: Pastuszkova, E., Crhova, Z., Vychytilova, J., Vytrhlikova, B. Knapkova, A. (eds.), Finance and Performance of Firms in Science, Education and Practice. pp. 370-384, Zlin, Czech Republic (2015).

13. Owen, A.L., Pereira, J.M.: Bank concentration, competition, and financial inclusion. Rev. Dev. Finance. 8, 1, 1-17 (2018).

14. Ponce, J., Rennert, M.: Systemic banks and the lender of last resort. J. Bank. Finance. 50, 286-297 (2015).

15. Soukal, I.: Directive 2007/64/ES legal harmonization impacts on CBS clients costs in CR. In: JEdlicka, P. (ed.), Hradecke ekonomicke dny 2010, DIL II: ekonomicky rozvoj a management regionu. Economic development and management region. pp. 105-108 (2010).

16. Soukal, I., Draessler, J.: Could Financial Literacy Overcome Price Information Asymmetry: Empirical Study. In: Kajurova, V, Krajicek, J. (eds.), European Financial Systems 2015: proceedings of the 12th international scientific conference. pp. 528-535 Masaryk University, Brno, Czech Republic (2015).

17. Soukal, I., Draessler, J.: Price Information Asymmetry Impact on Optimal Choice - RCBS Market Case Study. In: Kocourek, A. (ed.), Proceedings of the 12th International Conference Liberec Economic Forum 2015. pp. 144-153 Technical University of Liberec, Liberec, Czech Republic (2015).

18. Toader, O.: Quantifying and explaining implicit public guarantees for European banks. International Review of Financial Analysis. 41(October 2015), 136-147 (2015). DOI: 10.1016/j.irfa.2015.06.003.

19. Van Dijk Management Consultants, Centre for European Policy Studies: Market study of the current state of play in Member States regarding initiatives in bank fee transparency and comparability in personal current bank accounts, https://www.ceps.eu/system/files/1912012_market_study_en.pdf, last accessed 2018/11/26. 